\title{
Bir Kıraat Âlimi ve Muhaddis Olarak Halef b. Hişâm
}

\section{Khalaf Ibn Hisham as a Scholar of Qiraat and Hadith}

\section{Kahraman Bulgurcu}

Dr. Öğretim Görevlisi, Selçuk Üniversitesi, İslami İlimler Fakültesi,

Kur'an- Kerim Okuma ve Kıraat İlmi Anabilim Dalı

Lecturer PhD., Selçuk University, Faculty of Islamic Science,

Department of Quran Reading and Recitation Science

Konya/Turkey

kbulgurcu@gmail.com | https://orcid.org/0000-0002-1914-0703

\section{Article Type / Makale Tipi}

Research Article / Araștırma Makalesi

DOI: $10.33420 /$ marife. 917160

Article Information / Makale Bilgisi

Received / Geliș Tarihi: 15.04.2021

Accepted / Kabul Tarihi: 15.06.2021

Published / Yayın Tarihi: 30.06.2021

Cite as / Atıf: Bulgurcu, Kahraman. "Bir Kıraat Âlimi ve Muhaddis Olarak Halef b. Hişâm”. Marife 21/1 (2021), 439-458. https://doi.org/10.33420/marife.917160

Plagiarism / Intihal: This article has been reviewed by at least two referees and scanned via a plagiarism software. / Bu makale, en az iki hakem tarafindan incelendi ve intihal içermediği teyit edildi.

\section{(c) (1) $(9)$}

Copyright / Telif Hakkl: "This article is an open access article distributed under the terms and conditions of the Creative Commons Attribution-NonCommercial-NoDerivatives 4.0 (CC BY-NC-ND 4.0) International License." / "Bu makale Creative Commons Alıntı-GayriTicari-Türetilemez 4.0 (CC BY-NCND 4.0) Uluslar arası Lisansı altında lisanslanmıștır." 


\section{Bir Kıraat Âlimi ve Muhaddis Olarak Halef b. Hişâm}

Özet

Insanın dünyadaki ömrü sınırlıdır. Bu sınırlı zaman diliminde her insanın faklı meşguliyet alanları bulunmaktadır. Insanlardan bir kısmı ilme önem vermiș ve ilimle iștigal etmiștir. İlim ehli insanların çoğu, bir ilim alanında ihtisaslaşarak bu alanda tanınmıştır. Onlardan kimisi ise birkaç ilmî alanda derinleșerek ihtisas sahibi olmuştur. Bu gibi âlimler hicri ilk 5 asır gibi ilk zamanlarda biraz daha fazla iken, sonraki zamanlarda iyice azalmıştır. Tabakat kitaplarına bakıldığında İslam âlimlerinin kendilerini yetiştirdikleri ilimler, hocaları, talebeleri ve bu ilimlerde yazdıkları eserler hakkında bilgilere ulaşılabilmektedir. Böylece birkaç alanda mütehassıs olan âlimlerin, bu alanlardaki çalışmalarına tabakat kitaplarındaki bilgilerden ulaşılabilmektedir. Bu şekilde birkaç alanda kendini yetiştiren âlimlerden birisi de hicri 150-229 yılları arasında yaşamış olan Halef b. Hişâm'dır. O, kıraat ilminde temayüz etmiş ve yaşadığı dönemde, kıraat âlimi anlamına gelen mukrî lakabıyla tanınmıștır. Kıraat ilmi, Kur'an'ın okunmasını ele alan bilim dalı olduğu için Peygamberimize (s.a.s.) ilk ayetlerin indirilmeye başlanmasıyla birlikte kıraat ilmi de ön plana çıkmıştır. Çünkü Peygamberimiz (s.a.s.) kendisine indirilen âyetleri önce kendisi özenli bir șekilde okuyor ve vahiy kâtiplerine yazdırlyordu. Kur'an ayetlerini öğrenen sahâbî de öğrendiği ayetleri diğer sahâbîlere öğretiyordu. Nitekim Peygamber Efendimiz kurrâ olarak tanınan bazı sahâbeyi Kur'an öğretmeleri için çeşitli bölgelere göndermiştir. Aynı zamanda Peygamberimiz Kur'an'ı güzel okuyan bazı sahâbîleri övmüş ve Müslümanları Kur'an'ı güzel okumaya teşvik etmiştir. Kıraat ilmi İslami ilimler içinde bir önceliğe sahip olup, bu sebeple onun öğretimi de çok önem arz etmektedir. Nitekim Müslümanlar sahâbe neslinden itibaren her nesil de kıraat ilmine önem vermişler ve bunun sonucunda zamanla bu konuda mütebahhir olan kıraat imamları ortaya çıkmıştır. Onlardan öncelikle yedi tanesinin kıraati, kırâati seb‘a olarak ön plana çıkmış; bunlara üç tane imamın kıraatinin de ilave edilmesiyle on imamın okuyuşu kıraati aşere olarak meşhur olmuştur. Bu on kıraat, kıraat âlimleri ve ümmet tarafindan kabul görmüștür. İmam Halef kırâat-i seb'a sisteminde, altıncı kıraat imamı olan İmam Hamza'nın birinci râvisidir. Kırâati seb'a'ya üç kıraat imamının ilave edilmesi sonucu ortaya çıkan kırâat-i aşere denilen sistemde ise onuncu imam olarak kabul edilmiştir. Bu sistemde Halefül-Âșir diye isimlendirilen Imam Halef, kıraat ilminde ise " döneminin önemli kârîlerinden kıraat ilmini öğrenmiş ve ondan da birçok kişi kıraat ilmini öğrenmiştir. Bu çalışmada öncelikle kıraat ilminin kısa bir tarihçesi, sonra Halef b. Hişâm’ın kıraat ilmindeki konumu, hocaları, talebeleri, eserleri ve onu önemli kıraatlere ulaştıran isnad zinciri hakkında bilgi verilmiștir.

Çift yönlü bir âlim olması sebebiyle Halef b. Hişâm, kıraat ilminin yanında hadis ilmiyle de meşgul olmuştur. 0 , kendinden önceki tebeu't-tâbiîn nesli ile kendinden sonraki nesil arasında köprü konumunda olan muhaddislerden ve hadis râvilerinden biridir. İlk hadis kitapları olan İmam Mâlik'in Muvatta'sl, İbn Cüreyc, Ma'mer b. Râşid, Evzâî ve Süfyân es-Sevrîgibi âlimlerin eserleri onun hayatının ilk zamanlarında yazılmıştır. Yine Müsned türü eserler onun yaşadığı zaman dilimi olan hicri ikinci asrın sonları ile hicri üçüncü asrın başlarında ortaya çıkmaya başlamıştır. Hicri üçüncü asır hadis ilminin altın çağı olarak kabul edilir. Hadisle ilgili her konuda bu dönem de birçok eser telif edilmiştir. Halef b. Hişâm da 79 yılık ömrünün son 29 yıllık kısmını hicri üçüncü asırda yaşamıştır. Böyle önemli bir zaman diliminde yaşamış olması sebebiyle Imam Halef'in hadis ilmindeki konumu önem arz etmektedir. Onun hadis ilmindeki konumunu ortaya koymak için bu ilimdeki çalıșmaları tabakat ve hadis kitaplarından araştırılmıştır. Nitekim genel tabakat kitaplarının yanında muhaddislerin hayatını ele alan tabakat kitaplarında da onun hayatına yer verilmiștir. 0 , hadis alanında devrinin büyük muhaddislerinden ilim öğrenmiştir. Ondan da bazıları aynı zamanda eser sahibi olan muhaddisler rivayette bulunmuștur. Nitekim onun naklettiği rivayetler Kütüb-i Sitte imamlarından Müslim'in es-Sahîh'inde ve Ebû Dâvûd'un es-Sünen'inde bulunmaktadır. Yine Ahmed b. Hanbel ve Ebû Ya'lâ el-Mevsilî'in Müsnedleri'nde de ondan nakledilen rivayetler geçmektedir. Ayrıca cerh ve ta'dîl imamları da onu eserlerinde zikretmişler ve onun hâfız ve sika olduğunu belirtmişlerdir. Çalışmanın sonunda Halef $b$. Hişâm'ın hadisçiliği ve bu alandaki ilmi durumu incelenerek onun hadis ilmi alanındaki konumu ortaya konulmuștur.

Anahtar Kelimeler: Kıraat, Hadis, Halef b. Hişâm, Kırâat-i Așere, Kütüb-i Sitte. 


\section{Khalaf Ibn Hisham as a Scholar of Qiraat and Hadith}

\section{Summary}

Mankind has a limited life in this world. Every person has different occupations in this limited time. Some people attach importance to science and study it. Most of the people of science become experts in a specific branch of science and are recognized in that area. Some of them intensify themselves in several branches and become experts. While there were more scholars like these in the first fivecentury AH, later on, the number got lower. When examined the tabaqat books, anyone can get information about the Muslim scholars' fields where they improve themselves, their teachers, students, and the works in these fields. So, from the information in tabaqat boks, the works of scholars who are experts in several branches can be obtained. One of the scholars who improved themselves in several branches and lived between 150-229 years was Khalaf Ibn Hisham. He became distinguished in the science of qiraat and was recognized as "muqri "which means a scholar of qiraat.

Since the science of qiraat is a discipline that deals with the Quran recitation, it became prominent when the first verses were revealed to the prophet(pbuh). Firstly, the prophet(pbuh) himself recited the verses attentively, then he made his Companions write the verses. The companions who learned the verses, taught them to other companions. Then, the prophet(pbuh) sent the companions who were recognized as a qurra(people who memorized the verses flawlessly) to various regions to teach the Qur'an. At the same time, the prophet(pbuh) praised some companions who recited the Qur'an well and encouraged the Muslims to recite the Qur'an. The field of qiraat has great importance within Islamic sciences, so the teaching of the Qur'an is of equal importance. Since the time of companions Muslims have given importance to the field of qiraat at all times, as a result, imams of qiraat who have been savant on this issue have emerged. Of these Imams, seven stood out for their recitation (qiraat) were accepted as the seven main ways to recite the Qur'an.. By adding qiraats of three imams to these seven, the recitation styles of these ten imams have become famous as the ten qiraats. These ten qiraats have been accepted by qiraat imams and ummah. Imam Khalaf, in the system of seven qiraats, was the first narrator of Imam Hamza who was the sixth imam of qiraat. Imam Khalaf was accepted as the tenth imam in the system called ten qiraat systems. In this system, Imam Khalaf who was also referred to as Khalaf al-Ashir was signified with a sign " Hisham learned the science of qiraat from the important qaries(reciters) of the time. He and many other people learned the field of qiraat from him. In this study, primarily the short history of the field of qiraat, then information about the place, teachers, students, and works of Khalaf Ibn Hisham, and isnad chain which allowed him to access important qiraats are given.

Since he was an all-around person, in addition to the field of qiraat, Khalaf Ibn Hisham employed himself in the field of hadith. He was one of the scholars of hadith and narrators who had a function of bridge between the taba'at tabi'un generation before himself and the generations who were after himself. The books, which were first hadith books, the Muwatta of Imam Malik and the works of Ibn Jurayj, Ma'mer, Awza'i and Sufyan were written in the early of his life time. Also, Musnad kind works came out in the late of second century AH. and the early of the third century in the period in which he lived. The third century AH. is accepted as golden age of the field of hadith. Many works about all the subjects related to hadith were written in this period. Khalaf Ibn Hisham lived seventy nine years and last twenty years of his life was in the third century AH. Since he lived in such an important age, the place of Khalaf Ibn Hisham in the field of hadith is valuable. His works in this field were studied in hadith and tabaqat books to reveal his place in it. Indeed, besides the general tabaqat books, his life was included in the tabaqat books that included the lifes of hadith scholars. He got education of hadith from important hadith scholars in his time. Indeed, his narrations existed in Sahih of Muslim which was one of the kutub-i sittah, and in Sunan of Ebu Davud. There were narrations of him in Musnad of Ahmad b. Hanbal and Abû Ya'lâ al-Mawsilî. Also, the imams of Al-Jarh wa At-Ta'deel mentioned him in their works and stated that he was a hafiz and siqa(trustworthy narrator).At the end of the study, the place of Khalaf Ibn Hisham in the science of hadith was stated by studying the hadith scholarship and scientific situation of him in this profession.

Key words: Qiraat, Hadith, Khalaf Ibn Hisham, Ten Qiraat, Kutub al-Sittah. 


\section{Giriș}

Temel İslam bilimleri olarak bilinen tefsir, hadis, fikıh, kelam gibi ilimler İslam'ın temel iki kaynağı olan Kur'an ve Sünnet'ten neşet etmiştir. Kur'ân lafız ve metin olarak Allah (c.c.) tarafından Peygamberimize (s.a.v.) indirilmiş ve Cebrail'in (a.s.) kendisine talim ettiği şekliyle bize kadar ulaşmıştır. Kıraat, Peygamberimizin Kur'an'ı okuyuş keyfiyeti olmaktadır. ${ }^{1}$ Peygamberimiz Kur'an'ı, sünneti ve kıraati sahâbe nesline, sahâbe nesli de tabiîn nesline aktarmış ve sırasıyla her nesil kendisinden sonraki nesillere aktararak devam etmiștir.

Gerek sahâbe gerekse tâbiîn neslinden birçoğu bu ilimlerin bir kısmında söz sahibi iken, bir kısım âlimler ise bu ilimlerin çoğunda ihtisaslaşmışlardır. Bu durum birkaç nesil devam etmiştir. Fakat birkaç nesil sonra gelen âlimlerin birçoğu, sadece bir ilimde uzmanlaşırken; çok azı ise birkaç ilim dalında uzmanlaşabilmiştir. Ne yazık ki birkaç ilim dalında ihtisas sahibi olma gün geçtikçe azalmıştır. Böyle birkaç ilim dalında uzmanlaşmış âlimlerin geniş bir ufka ve derin bir kültür anlayışına sahip oldukları anlaşılmaktadır. Nitekim bu şekildeki ilim ehli insanların çok olduğu dönemlerde Müslümanların dünyada ilim ve medeniyet alanında öncü oldukları görülmektedir. Günümüzde böyle âlimlerin tanıtılarak müslümanların ve ilim ehli insanların teşvik edilmesi önem arzetmektedir.

İlk dönem âlimlerinden bir kısmı hadisin yanında kıraat ilmini de öğrenmişler ve çift alanda kendilerini yetiştirmiş̧lerdir. Bu âlimlerden bir kısmı bu iki alanda uzman olmakla birlikte birinde ön plana çıkmış ve bu alanda daha çok eser vermişlerdir. Zikrettiğimiz hususa örnek âlimlerden biri de daha çok kıraat alanında meşhur olan Halef b. Hişâm'dır.

Sahih yedi kıraat imamlarından Hamza b. Habîb'in (ö. 156/773) birinci râvisi olan İmam Halef (ö. 229/844), aynı zamanda sahih kıraatlerden yaptığı tercihlerle kendine ait bir kıraat ekolü oluşturarak meşhur on kıraat imamından biri olarak kıraat ilminde ismi ön planda zikredilmiștir. Kıraat ilminin yanında yaşadığı dönemin muhaddislerinden hadis öğrenmiş ve kendisinden de rivayette bulunulmuştur. Kendilerinden hadis aldığı muhaddisler arasında Mâlik b. Enes, Hüşeym b. Beşîr el-Vâsıtî, Ebu'l-Ahves Sellâm b. Süleym el-Kûfí, Ebû Avâne el-Vâsıtî ve Hammâd b. Zeyd zikredilebilir. ${ }^{2}$ Ondan da Ahmed b. Hanbel, Müslim b. el-Haccâc el-Kușeyrî, Ebû Dâvûd es-Sicistânî, Ebû Hâtim er-Râzî, Ebû Zür'a er-Râzî, İdrîs b. Abdülkerim el-Haddâd ve Ebû Ya'lâ el-Mevsılî gibi âlimler hadis rivayet ettiler. ${ }^{3}$ Onun rivayetleri Kütüb-i Sitte'de Müslim'in el-Câmiu's-Saḥ̂ḥ̣'inde ve Ebû

${ }^{1}$ Kurân ve kıraat iki ayrı hakikat mi yoksa Kur'ân ve kıraat aynı hakikat mi? Görüşler için bkz. Murat Akkuș, Ramazan Aydın, "Türkiye'deki Farklı Kıraat Anlayışlarıyla İlgili Değerlendirmeler". Mütefekkir 3 / 6 (Aralık 2016): 289-306.

2 Bk. Ebü'l-Haccâc Cemâlüddîn Yusuf b. Abdirrahmân el-Mizzî, Tehzîbü'l-Kemâl fì Esmâi'r-Ricâl (Beyrut: Müessesetü'r-Risâle, 1400/1980), 8/300; Ebû Abdillâh Şemsüddîn Muhammed b. Ahmed b. Osmân ez-Zehebî, Siyeru A'lâmi'n-Nübelâ (Beyrut: Müessesetü'r-Risale, 1410/1990), 10/577; Ebü'l-Fazl Şihâbüddîn Ahmed b. Alî b. Muhammed el-Askalânî, Tehzîbü't-Tehzîb (Haydarâbâd: Dâiratü'lMeârifi'n-Nizâmiyye, 1325), 3/156.

${ }^{3}$ Mizzî, Tehzîbü'l-Kemâl, 8/300-301; Zehebî, Siyer, 10/577; İbn Hacer, Tehzîbü't-Tehzîb, 3/156. 
Dâvûd'un es-Sünen'inde ayrıca Ahmed b. Hanbel ve Ebû Ya'lâ el-Mevsılî̀nin Müsnedler'inde geçmektedir.

$\mathrm{Bu}$ araştırmada öncelikle kıraat ilminin tarihçesi hakkında bilgi verilecek sonrasında ise İmam Halef'in kıraat ve hadis ilmiyle ilgili yönü incelenmek suretiyle onun bu iki ilimdeki konumu ortaya konulmaya çalışılacaktır.

\section{Kıraat İlminin Tarihçesi}

Kıraat ilminin farklı tanımları olmakla birlikte İbnü'l-Cezerî̀ye (ö. 833/1429) ait olan, "Kur'an kelimelerinin nasıl okunacağını ve râvilerine nispet etmek suretiyle bu kelimeler üzerindeki farklı okuyuşları konu edinen bir ilimdir." şeklindeki tanımı daha kapsayıcı ve meşhur olanıdır. ${ }^{4}$

Müslümanlar Kur'an'ın indirilmeye başlamasından itibaren her zaman diliminde kıraat ilmiyle ilgilenmişlerdir. Çünkü Peygamberimiz (s.a.s.) kendisine indirilen âyetleri önce kendisi özenli bir şekilde okuyor ve hemen ashabına aktarıyordu. Bu sebeple kıraat ilminin, İslâmî ilimler içinde ortaya çıkış zamanı ve önemi bakımından önceliğe sahip olduğu tartışılmaz bir gerçektir. Nitekim Peygamber Efendimiz kurrâ olarak tanınan bazı sahâbeyi Kur'an öğretmeleri için çeşitli bölgelere göndermiștir. Aynı zamanda Peygamberimiz Kur'an'ı güzel okuyan bazı sahâbîleri överek ${ }^{5}$ Kur'an'ı güzel okumaya teşvik etmiştir. Râsulullah (s.a.s.) döneminde Hz. Osman, Hz. Ali, İbn Mes'ud, Übeyy b. Ka‘b, Muaz b. Cebel, Zeyd b. Sâbit, Ebû Musa el-Eş'arî, Sâlim Mevlâ Ebî Huzeyfe ve Ebu'd-Derdâ gibi sahâbîler kıraatte ön plana çıkmıştır. ${ }^{6}$

Tarihi süreçte kıraat ilmiyle alakalı asıl meselelerden biri olan ve kıraat farklılığının temelini oluşturan "yedi harf" ruhsatı 7 İslam âlimleri arasında tartışma konusu olmuştur. Sahâbe, Peygamberimizin irtihalinden sonra da Kur'an-ı Kerim kıraatine ehemmiyet göstermiş ve bu farklılıkları korumuşlardır. Kur'an âyetlerinin Hz. Ebû Bekir zamanında Mushaf halinde cem edilmesi ve Hz. Osman döneminde Hz. Ebû Bekir'in cem ettirdiği Mushaf'ın istinsah edilerek çoğaltılması esnasında Kur'an ve kıraat bilgisi konusunda yetkin olan bu sahâbîlerden faydalanılmıştır. ${ }^{8}$

Rasûlullah (s.a.s.) kendisine indirilen ayetleri hem vahiy kâtiplerine yazdırı-

4 Ebü'l-Hayr Şemsüddin Muhammed b. Muhammed el-Cezerî, Müncidü'l-Mukri'în ve Murşidü’t-Tâlibîn (Beyrut: Dâru'l-Kütübi'l-İlmiyye, 1420/1999), 9.

5 Ebû Abdillâh Muhammed b. İsmail el-Buhârî, Sahîhu'l-Buhârî (İstanbul: Çağrı Yayınları, 1992), "Fezâilü’l-Kur’an", 8.

6 Ebü’l-Fazl Celâlüddîn Abdurrahmân b. Ebî Bekr b. Muhammed el-Hudayrî es-Süyûtî, el-İtkân fi Ulûmi'l Kur'an, thk. Şuayb el-Arnavûd (Beyrut: Müessesetü'r-Risâle, 1429/2008), 157-158; İsmail Cerrahoğlu, Tefsir Usulü (Ankara: TDVY, 1985), 68-69.

7 Yedi harf ruhsatı ile ilgili rivayetlerden bazıları için bk. Buhârî, Sahîhu'l-Buhârî, "Fezâilü’l-Kur'an”, 5; Ebü'l-Hüseyn Müslim b. el-Haccâc el-Kușeyrî, Sahîh-i Müslim, (İstanbul: Çağrı Yayınları, 1992), "Salâtü'l-Müsâfirîn ve Kasrihâ", 270, 271; Ebû Amr Osmân b. Saîd b. Osmân ed-Dânî, el-Ahrufü'sSeb'a li'l-Kur'an (Mekke: Mektebetü'l-Menâra, 1408/1988), 11-17.

8 Buhârî, Sahîhu'l-Buhârî, "Fezâ’ilü'l-Kur’an”, 3; Abdulhamit Birıșık, "Kıraat", Türkiye Diyanet Vakfı İslâm Ansiklopedisi (İstanbul: TDV Yayınları, 2002), 25/427. 
yor $^{9}$ hem de onların yazdıkları yazılı nesneleri kendi yanında koruyordu. ${ }^{10}$ Rasûlullah'tan Kur'an'ı öğrenen ve kendilerine ait özel Kur'an nüshası yazan bazı sahâbîler duruma göre farklı yerlere gidiyorlardı. Ancak Kur'an'ın inmesinin devam etmesi, yedi harf izni ve Arap hattının çok gelişmemiş olması gibi nedenlerle gittikleri bölgelerde sahâbenin farklı kıratleri, ilk zamanlar bir problem oluşturmazken Peygamberimizin vefatından sonraki senelerde Kur'an kıraati hususunda bazı ayrılıklar hâsıl olmuștur. ${ }^{11}$ Kur'an'ın Hz. Ebû Bekir döneminde cem edilmesiyle tam olarak son bulmayan bu ayrılık, Hz. Osman'ın Kur'an'ı indirildiği Kur eyş lehçesiyle istinsah etmesi ve farklı bölgelere göndermesi neticesinde son bulmuştur. Bunun yanında Hz. Osman'ın, hilafet yetkisini kullanarak hususi Kur'an nüshalarının yok edilmesiyle ilgili kesin emri de bu ayrılıkların nihayete ulaşmasında önemli bir etken olmuştur. ${ }^{12}$ Kur'an'ın Kureyş lehçesine göre istinsah edilmesi ve bu yazmalarda hareke ve noktanın bulunmaması sebebiyle çoğaltılan nüshaların hattının Peygamberimizden nakledilen farklı kıraat vecihlerine de ihtimali bulunmaktaydl. ${ }^{13}$

Hz. Osman'ın Mushaflarla beraber gönderdiği kâriler, beraberlerindeki mushafa uygun olan kıraatleri bulundukları șehirde yaymışlardır. Böylece sahâbenin Peygamberimizden aldıkları bu farklılıklar tâbiîn ve sonraki nesillerde de devam etmiştir. Bunun neticesinde öncelikle çoğaltılan mushafların gönderildiği vilayetler olmak üzere kıraat ilim merkezleri ortaya çıkmıştır. Kıraat alanında yazılan ilk telifatın hicri 70 ve 80’li yıllarda ortaya çıktığı görülmektedir. Bu da büyük kıraat âlimlerinin çoğunun tâbiîn neslinden olduğunu ve kıraat ilminin kısa süre içinde çok ilerlediğini ortaya koymaktadır. Hicrî ilk üç asırda çoğunlukla Medine, Mekke, Şam, Basra ve Kûfe gibi vilayetlerde artan kıraat faaliyetleri, daha sonra yapılan fetihlerle diğer İslam beldelerine de ulaşmıştır. Bunun sonucunda Müslümanlardan pek çok kimse Kur'an-ı Kerim'in lafızlarını, okunuş şekillerini, vücûh ve edasını zabt ve öğrenmeye vakfedip, bu yolda ümmetin kendilerine ittiba ettikleri kişiler olmuşlardır. Kırâat-i seb'a ve aşere imamları da bunlardandır. ${ }^{14}$

Sahih kıraatin şartlarını taşımakla birlikte rivayet ve okuyuşlar arasında tercihleri bulunan kârilerin sayıları ilk zamanlar çok iken zamanla bunlardan bazıları ön plana çıkmış; bunun sonucunda ilk kıraat ekolleri ortaya çıkmıştır. Kıraatle

9 Osman Keskioğlu, Kur'an-ı Kerim Bilgileri (Ankara: TDVY, 1989), 73-74; Muhammed Mustafa A‘zamî, Vahyedilișinden Derlenișine Kur'an Tarihi, çev. Ömer Türker ve Fatih Serenli (İstanbul: İz Yayıncılık, 2006), 105-108.

10 Ebû Zeyd Ömer b. Şebbe en-Nümeyrî el-Basrî, Târîhu'l-Medîneti'l-Münevvere, thk. Fehîm Muhammed Şeltût (Cidde: Habib Mahmud Ahmed Kütüphanesi, 1399/1979), 3/990-991. (İbn Şebbe'nin eserinde geçtiğine göre Abdullah b. Zübeyr, Rasulullah'ın yazdırdığı sahifelerin Hz. Osman'ın hilafeti zamanında Hz. Aișe'nin yanında olduğunu bildirmektedir.); Birıșık, "Kıraat", $25 / 427$.

11 Birıșık, "Kıraat", 25/427.

12 Muhammed Mustafa A'zamî, Vahyedilişinden Derlenişine Kur'an Tarihi, 129-140; Mehmet Emin Maşalı, Tarihi ve Temel Meseleleriyle Kıraat İlmi (Ankara: Otto Yayınları, 2020), 31.

13 A‘zamî, Vahyedilişinden Derlenișine Kur'an Tarihi, 137; Abdurrahman Çetin, Kur'ân-ı Kerîm’in İndirildiği Yedi Harf ve Kıraatlar (İstanbul: Ensar yayınları, 2013), 218; Recep Koyuncu, Kıraat İlmi ve Takrîb Usulü (Konya: Hacıveyiszade İlim ve Kültür Vakfi, 2018), 35.

14 Birışık, "Kıraat”, 25/427; Koyuncu, Kıraat İlmi ve Takrîb Usulü, 35-36. 
ilgili yazılan ilk eserler ve çalışmalar incelendiğinde pek çok kıraatin olduğu anlaşılmakta ve kendi içinde tutarlılığı olan kıraatlerin adedinin ise otuz civarında olduğu görülmektedir. Ebû Ubeyd Kâsım b. Sellâm (ö. 224/838) kıraatle ilgili Kitâbü'l-Kırâât adlı eserinde otuz iki ve İbn Cerîr et-Taberî (ö. 310/923) kıraate dair kitabında yirmi civarında kıraati cem etmişlerdir. ${ }^{15}$ Ebû Bekir b. Mücâhid (ö. 324/936), Kitâbü’s-Seb`a fi'l-Kırâât isimli eserinde yedi kıraat imamının kıraatlerini toplayarak kıraatleri yediye tahsis eden ilk kişi olmuştur. ${ }^{16}$ İbn Mücâhid'in, bu seçimi kıraat ilminin tarihinde bir dönüm noktası olmuş ve "kırâat-i seb'a" konusunda ümmetin icmâl meydana gelmiştir. ${ }^{17}$ Yine onun kıraat imamları konusunda yaptığı isabetli seçim ve bu alandaki otoritesi sebebiyle kitabı gerekli ilgiyi görerek sonraki nesiller arasında meşhur olmuş ve kıraatle ilgili kitapların temelini oluşturmuştur. Bunun neticesinde Mekke'de Ebû Ma'bed İbn Kesîr, Medine'de Nâfi‘ b. Abdurrahman, Şam'da İbn Âmir, Kûfe'de Ebû Bekir Âsım b. Ebi'n-Necûd, Hamza b. Habîb ve Alî b. Hamza Kisâî ve Basra'da Ebû Amr b. Alâ'nın kıraatinden meydana gelen "yedi kıraat" meşhur olmuştur. ${ }^{18}$ Sonra kıraatler okuyucusuna nispet edilerek Nâfî kıraati, İbn Kesîr kıraati adıyla zikredilmişlerdir. Daha sonra bir kısım âlimler yedi imama üç imam daha ilave ederek sayıyı ona çıkarmışlardır. Ahmed b. el-Hüseyn b. Mihrân en-Nîsâbûrî (ö. 381/992), on kıraatle ilgili el-Gâye fi'l-Kırââti'l'Aşr adlı eserinde bu yedi kıraate Ebû Cafer el-Kârî (ö. 130/748), Yakub el-Hadramî (ö. 205/821) ve Halef b. Hişâm (ö. 229/844) kıraatlerini ekleyerek "kırâat-i aşere"yi ortaya koyan ilk müelliftir. ${ }^{19}$ Onlu tasnifi kıraat öğretiminde bir metod haline getiren İbnü'l-Cezerî olmuştur (ö. 833/1429). İbnü'l-Cezerî̀nin en-Neşr fi'lKırââti'l-Aşr, Tayyibetü'n-Neşr ve Takrîbü'n-Neşr gibi kitaplarıyla kıraat öğretiminde seb'a tarikinin yerini aşere almış ve zamanla bütün İslâm âlemi tarafından kabul görmüştür. ${ }^{20}$

\section{Bir Kıraat Âlimi Olarak Halef b. Hişâm}

Ebû Muhammed Halef b. Hişâm b. Sa'leb el-Esedî el-Bağdâdî el-Bezzâr 150/767 senesinde dünyaya geldi. Aslen Femü's-Sılh beldesinden olduğu için Sılhî, sonra ise Bağdat'ta ikamet ettiği için Bağdâdî nisbesiyle bilinir. Tahıl satan kimse anlamındaki "Bezzâr" lakabıyla anılmaktan hoşlanmamış, kendisine "mukrî" denilmesini istemiştir. ${ }^{21}$

Küçük yaşta ilim hayatına başlayan İmam Halef, on yaşında Kur’ân-ı Kerîm'i

15 Maşalı, Tarihi ve Temel Meseleleriyle Kıraat İlmi, 51-53; Koyuncu, Kıraat İlmi ve Takrîb Usulü, 46.

16 Ebû Bekir Ahmed b. Mûsâ b. el-Abbâs b. Mücâhid et-Temîmî, Kitâbü’s-Seb`a fi'l-Kırâât (Kahire: Dâru'l-Meârif, 1972), 53-87.

17 Mehmet Dağ, Geleneksel Kıraat Algısına Eleştirel Bir Yaklaşım (Ankara: Türkiye Diyanet Vakfı Yayınları, 2019), 284-287; Maşalı, Tarihi ve Temel Meseleleriyle Kıraat İlmi, 56-57.

18 Keskioğlu, Kur'an-ı Kerim Bilgileri, 158; Maşalı, Tarihi ve Temel Meseleleriyle Kıraat İlmi, 61-62.

19 Ali Eroğlu, "İbn Mihrân en-Nîsâbûrî" Türkiye Diyanet Vakfi İslâm Ansiklopedisi (İstanbul: TDV Yayınları, 1999), 20/199; Dağ, Geleneksel Kıraat Algısına Eleştirel Bir Yaklaşım, 286-287.

20 Tayyar Altıkulaç, “İbnü’l-Cezerî” Türkiye Diyanet Vakfı İslâm Ansiklopedisi (İstanbul: TDV Yayınları, 1999), 20/553; Birıșık, "Kıraat”, 25/427-428.

21 İbnü’l-Cezerî, Ebü'l-Hayr Şemsüddin Muhammed b. Muhammed el-Cezerî, Gâyetü'n-Nihaye fî Tabakâti'l-Kurrâi (Beyrut: Dâru'l-Kütübi'l-İlmiyye, 1427/2006), 1/246. 
hıfz etmiş ve on üç yaşında iken Kur'an öğretimine başlamıştır. ${ }^{22}$ İmam Halef' (ö. 229/844) birçok kıraat âliminden ders almış, kıraat ilminde ihtisaslaşarak meşhur olmuş ve kıraati de mütevâtir on kıraat arasında sayılmıştır. 0, İbn Mücâhid (ö. 324/936) ile başlayan ve âlimler tarafından da kabul gören, kırâat-i seb'a sisteminde, altıncı kıraat imamı olan İmam Hamza'nın birinci râvisidir. Bu yöntemde Halef'in rumuzu "ض"dır. Kırâat-i seb'a’ya üç kıraat imamının ilave edilmesi sonucu ortaya çıkan kırâat-i aşere denilen sistemde ise onuncu imam olarak kabul edilmiştir. Bu sistemde Halefü'l-Âşir diye isimlendirilen İmam Halef, kıraat ilminde ise " خل " rumuzu ile adlandırılmıştır. ${ }^{23}$

İmam Halef kıraat ilmini kırâat-i seb'a imamlarından İmam Nâfi', İmam Âsım, İmam Ebû Amr ve İmam Hamza'dan direkt alamamış; onların talebeleri aracılığıyla almıştır. İmam Kisâî'nin kıraatini de dinleyerek zabt etmiş ve rivayette bulunmuştur. Yine imam İbn Kesîr kıraatini ise onun talebesinin ${ }^{24}$ talebesi olan Ubeyd b. Akîl'den öğrenmiştir. ${ }^{25}$

On dokuz yaşında iken, Kûfe'de Âsım b. Ebi'n-Necûd Behdele'nin ünlü iki talebesinden biri olan Ebû Bekir Şube b. Ayyâş̧tan kıraat dersi öğrenmek için Süleym b. Îsâ'nın yazdığı referans mektubu ve oğlu ile birlikte Ebû Bekir'in evine gitmişler; Ebû Bekir'in mektubu okuduktan sonra söylediği, "Bağdat'ta senden daha iyi okuyan birini bırakmamışsın, öyle mi?” anlamındaki sözünü aşağllama olarak düşünmüş ve hemen Ebû Bekir'in evini terk etmiştir. Fakat İmam Halef daha sonra bu davranışından pişmanlık duymuş ve İmam Âsım'ın kıraatini, Ebû Bekir'in öğrencisi olan Yahyâ b. Âdem'den öğrenmiştir. ${ }^{26}$

Onun kendilerinden ilim aldığı hocaları ve onlardan aldığı kıraatler şunlardir: okudu. ${ }^{27}$

1. İshak el-Müseyyebî'den (ö. 206/821) Nâfi' b. Abdurrahman'ın kıraatini

2. Ubeyd b. Akîl'den, İbn Kesîr kıraatini ve Kuteybe rivayetini okudu. ${ }^{28}$

3. İsmail b. Ca'fer (ö. 180/796) ve Abdülvahhab b. Atâ'dan (ö. 204/819) Ebû Amr kıraatini aldı. ${ }^{29}$

22 Ebû Abdillâh Semsüddîn Muhammed b. Ahmed b. Osmân ez-Zehebî, Ma'rifetü'l-Kurrâi'l-Kibâr AletTabakâti ve'l-Âsâr (İstanbul: Türkiye Diyanet Vakfı İslam Araștırmalar Merkezi Yayınları, 1995), 1/422; İbnü'l-Cezerî, Gâyetü'n-Nihaye, 1/246.

23 Sirâceddin Öztoprak, Kur'an Kıraatı -Kıraâtı Așere (İstanbul: Beyan Yayınları, 2012), 197.

24 İbn Kesîr'in talebesi ve Ubeyd b. Akîl'in hocası Abdullah b. Zeyd b. Yezîd el-Mekkî'dir (Bk. İbnü'lCezerî, Gâyetü'n-Nihaye, 1/376).

25 İbnü'l-Cezerî, Gâyetü'n-Nihaye, 1/247; Tevfîk İbrahim Damra, Ferhatü'l-Ebrâr fî Kırâat-i Halefi'lBezzâr (Amman: Dâru's-Sahâbe, 1429/2008), 11; Cafer Yerlikaya, Halef el-Bezzâr ve Kırâati (Sivas: Cumhuriyet Üniversitesi, Sosyal Bilimler Enstitüsü, Yüksek Lisans, 2014), 37.

26 Zehebî, Ma'rifetü’l-Kurrâi'l-Kibâr, 1/421; Tayyar Altıkulaç, "Halef b. Hişâm”, Türkiye Diyanet Vakfi İslâm Ansiklopedisi (İstanbul: TDV Yayınları, 1997), 15/237.

27 Zehebî, Ma'rifetü'l-Kurrâi'l-Kibâr, 1/419; İbnü'l-Cezerî, Gâyetü'n-Nihaye, 1/247; Damra, Ferhatü'lEbrâr fî Kırâat-i Halefi'l-Bezzâr, 11.

28 İbnü'l-Cezerî, Gâyetü'n-Nihaye, 1/247; Damra, Ferhatü'l-Ebrâr fî Kırâat-i Halefi'l-Bezzâr, 11.

29 İbnü'l-Cezerî, Gâyetü'n-Nihaye, 1/247; Damra, Ferhatü'l-Ebrâr fî Kırâat-i Halefi'l-Bezzâr, 11. 
4. Ebû Yûsuf Yakub b. Halîfe el-A'şân ${ }^{30}$ (ö. 200/815) ve Yahyâ b. Âdem'den de (ö. 203/818) Ebû Bekir Şu'be b. Ayyâş31 (ö. 193/809) vasıtasıyla Âsım b. Behdele’nin kıraatini öğrendi. ${ }^{32}$

5. Süleym b. İsa (188/804) ve Abdurrahman b. Ebû Hammâd'dan Hamza b. Habîb'in kıraatini öğrendi. ${ }^{33}$

6. İmam Kisâî̀nin kıraatini Kur'ân-ı Kerîm'in sonuna kadar Kisâî’den dinledi. $^{34}$

7. Zâide b. Kudâme'den (ö. 161/777) A'meș b. Muhaysın'ın kıraatini aldı. ${ }^{35}$

8. Ebû Yûsuf Yakub b. Halîfe el-A'şâ (ö. 200/815) ve Ebû Zeyd Saîd b. Evs'den (ö. 215/830) ${ }^{36}$ onların Mufaddal ed-Dabbî'den (ö. 178/794) aldığı kıraati okudu. Mufaddal İmam Âsım ${ }^{37}$ ve A'meş'ten ${ }^{38}$ kıraat almıștır. Fakat kaynaklarda Mufaddal'dan kıraat dersi alan İmam Halef'in zikri geçen iki hocasının ondan hangi kıraati aldıklarıyla ilgili bir bilgiye rastlanılmamıştır.

Verilen bilgilerden de anlaşıldığı gibi İmam Halef (ö. 229/844) birçok mütevâtir kıraati, o kıraatlerin imamlarından doğrudan alamamış; aksine onların râvilerinden veya râvilerin talebelerinden öğrenmiştir. Onun, İmam İbn Kesîr (ö. 120/738), İmam Âsım (ö. 127/745) ve İmam Hamza'dan (ö. 156/773) doğrudan ilim alması mümkün değildir. Çünkü o, İmam İbn Kesîr'in ölümünden 30, İmam Âsım'ın ölümünden 23 yıl sonra dünyaya gelmiş; ayrıca İmam Hamza öldüğünde ise 6 yaşında bir çocuk olduğu için ondan da ders alamamıştır. İmam Nâfi' (ö. 169/785) vefat ettiğinde, İmam Halef 19 yaşında olmasına rağmen ondan direkt ders alma imkânı olmamıştır. Yine o, İmam Kisâî'den (ö. 189/805) Kur'ân-ı Kerîm'i sonuna kadar dinlemiş fakat ona arz etmemiştir. İmam Halef'in kendilerinden klraat ilmi aldığı hocalarının Peygamberimize kadar ulaşan muttasıl senedleri bulunmaktadır. ${ }^{39}$

Halef b. Hişâm, Kırâat-i seb‘a imamlarından Hamza b. Habîb’den kıraat ilmini doğrudan almamış olmasına rağmen İmam Hamza'nın birinci râvisi olarak kabul edilmiştir. İmam Halef, Hamza b. Habîb'in kıraatine aykırı şekilde gelen farklı rivayetlerden yaptığı 120 yerdeki uygun tercihleri nedediyle de İbnü'l-Cezerî̀nin (ö. 833/1429) kıraat imamları sıralamasında onuncu imam olarak sayılmıștır. Nite-

30 Zehebî, Ma'rifetü'l-Kurrâi'l-Kibâr, 1/419.

31 Kur'an'ın anlaşılmasında Ebû Bekir Şu'be rivayetinin rolüyle ilgili şu makaleye bakılabilir. Murat Akkuş, Haşem Yılmaz "Ebû Bekir Şu'be Rivayetinin Kur'ân'ın Anlaşılmasındaki Rolü”, SIRAT 1/2 (Kasım-2020), 142-169.

32 Zehebî, Ma'rifetü'l-Kurrâi'l-Kibâr, 1/419; Altıkulaç, “Halef b. Hişâm, 15/237.

33 İbnü'l-Cezerî, Gâyetü'n-Nihaye, 1/247; Damra, Ferhatü'l-Ebrâr fî Kırâat-i Halefi'l-Bezzâr, 11.

34 İbnü'l-Cezerî, Gâyetü'n-Nihaye, 1/247. Damra, Ferhatü'l-Ebrâr fî Kırâat-i Halefi'l-Bezzâr, 11.

35 İbnü'l-Cezerî, Gâyetü'n-Nihaye, 1/247. Damra, Ferhatü'l-Ebrâr fî Kırâat-i Halefi'l-Bezzâr, 11.

36 İbnü'l-Cezerî, Gâyetü'n-Nihaye, 1/247; Damra, Ferhatü'l-Ebrâr fî Kırâat-i Halefi'l-Bezzâr, 11.

37 İbnü'l-Cezerî, Gâyetü'n-Nihaye, 1/316; 2/268; İbnü'l-Cezerî, en-Neșr, 1/191.

38 İbnü'l-Cezerî, Gâyetü'n-Nihaye, 2/268.

${ }^{39}$ Ebü'l-Hayr Şemsüddin Muhammed b. Muhammed el-Cezerî, en-Neşr fi'l-Kırââti'l-Aşr, nşr. Ali Muhammed ed-Dabbâ‘ (Beyrut: Dârü'l-Kütübi'l-İlmiyye, ts.), 1/191; Cafer Yerlikaya, "Halef Kırâati Özelinde Kırâatlerle İlgili Bazı Tahlil ve Tespitler”, KSÜ İlahiyat Fakültesi Dergisi 36 (Aralık 2020), 320. 
kim İbnü'l-Cezerî, onun Hamza'ya aykırı olarak yaptığı tercihleri incelemiş; biri hariç bunların Kûfeliler'e ve özellikle Hamza, Kisâî ve Ebû Bekir Şu'be b. Ayyâş̧a ait kıraatlerin haricinde düşünülemeyeceğini belirtmiştir. ${ }^{40}$ Kıraat ilmiyle ilgili eserlerde Halef in onuncu imam olduğu düşüncesi genellikle kabul görmüş olsa da bazı kaynaklarda onun yerine İbn Muhaysın (ö. 123/741) tercih edilmiștir. Halef'in k1raatine ise "İhtiyâru Halef" başlığı altında değinilmiştir. ${ }^{41}$

Halef b. Hişâm'dan (ö. 229/844) kıraat ilmini arz ve sema yoluyla öğrenen talebeleri arasında Ebü'l-Hasen Ahmed b. Yezîd el-Hulvânî (ö. 250/864), Muhammed b. İsa b. İbrahim (ö. 253/867), Ahmed b. İbrahim el-Verrâk (ö. 270/883), Ebû Muhammed Seleme b. Âsım (ö. 270/883+), Muhammed b. el-Cehm (ö. 277/890), Ahmed b. Züheyr b. Harb ${ }^{42}$ (ö. 279/892), İshâk b. İbrâhîm b. Osmân el-Verrâk (ö. 286/899), İdrîs b. Abdilkerîm el-Bağdâdî (ö. 292/905), Muhammed b. Mahled elEnsârî (ö. 300/913), Ahmed b. Muhammed b. Halid el-Berâsî (ö. 302/915), Ali b. elHüseyn b. Selim, İbrahim b. Ali el-Kassâr, Muhammed b. Saîd b. Imrân ed-Dârîr, elFadl b. Ahmed b. Mansûr ez-Zebîdî, Ali b. Muhammed b. Nâzik, Ebü'l-Velîd Abdülmelik b. el-Kâsım, Abdullah b. Âsım, Muhammed b. İshak, İbrahim b. İshak, Muhammed b. İbrahim ve Musa b. İsa gibi âlimler bulunmaktadır. ${ }^{43}$

İmam Halef, kıraat konusunda mütehassıs öğrenciler yetiştirmiş olup, onlardan bazıları aynı zamanda eser sahibi kimselerdir. ${ }^{44}$ Yine öğrencilerinden iki tanesi aynı zamanda onun kıraatinin de râvileridir. Birinci râvisi Ebû Yakub İshâk b. İbrâhîm b. Osmân el-Verrâk el-Mervezî (ö. 286/899) olup kıraat ilmindeki rumuzu "سح"dır. İkinci râvisi ise Ebü'l-Hasen İdrîs b. Abdülkerîm el-Haddâd elBağdâdî (ö. 292/905) olup kıraattaki rumuzu "سه"dir.45

Halef b. Hişâm kıraat alanında öğrenciler yetiştirmekle birlikte bu konuda eserler de vermiștir. Kaynaklarda Kitâbü'l-Kırâât, Kitâbü'l-'Aded, Müteşâbihü'lKur'ân ve İhtilâfü'l-Mesâhif adlı eserleri zikredilmektedir. ${ }^{46}$ Ancak bunların günümüze ulaşıp ulaşmadığıyla ilgili elimizde bir bilgi bulunmamaktadır. ${ }^{47}$

Hakkında âlimlerin övücü sözler söylediği İmam Halef'le ilgili Abbas b. Muhammed ed-Dûrî (ö. 271/884), Hamza b. Habîb'in diğer ravisi Hallâd b. Hâlid (ö. 220/835) dışında Halef'ten daha güzel okuyan bir mukrî görmediğini söylerken;48

40 İbnü'l-Cezerî, en-Neșr, 1/191; Altıkulaç, “Halef b. Hișâm”, 15/237.

${ }^{41}$ Altıkulaç, "Halef b. Hişâm”, 15/237; a.mlf., “İbn Muhaysın” Türkiye Diyanet Vakfi İslâm Ansiklopedisi (İstanbul: TDV Yayınları, 1999), 20/209-210; Öztoprak, Kur'an Kıraatı, 198.

42 Meşhur muhaddis Züheyr b. Harb'in oğludur.

43 Zehebî, Siyer, 10/577; İbnü'l-Cezerî, Gâyetü'n-Nihaye, 1/247.

${ }^{44}$ Ahmed b. Züheyr b. Harb'in tarihle ilgili meşhur eseri bulunmaktadır (Bk. İbnü'l-Cezerî, Gâyetü’nNihaye, 1/54). Seleme b. Âsım'ın Garîbü'l-Hadîs ve Kitâbü'l-Meslûk adlı eserinin olduğu zikredilmektedir. (Bk. İdris Şengül, Türkiye Diyanet Vakfi Íslâm Ansiklopedisi, "Seleme b. Âsım" 36/405-406). Muhammed b. İsa b. İbrahim'in ise kıraatle ilgili eserleri vardır (Bk. İbnü'l-Cezerî, Gâyetü'n-Nihaye, 2/197).

45 Öztoprak, Kur'an Kıraatı, 253-254.

${ }^{46}$ Altıkulaç, "Halef b. Hişâm", 15/237; Öztoprak, Kur'an Kıraatı, 199.

${ }^{47}$ Altıkulaç, "Halef b. Hişâm", 15/237.

${ }^{48}$ Ebû Muhammed Abdurrahmân b. Muhammed b. İdrîs er-Râzî, el-Cerh ve't-Ta'dîl (Beyrut: Dâru İhyâi'tTürâsi'l-Arabî, 1371/1952), 3/372 
el-Hüseyin b. Fehm (ö. 289/902) de Halef'ten daha şerefli birini tanımadığını bildirmiş ve ayrıca onun ders vermeye ilk olarak Kur'an okuyan öğrencilerinden başladığını, sonra ise hadis öğrencilerine ders verdiğini söylemiștir. ${ }^{49}$ İbn Hibbân (ö. 354/965) onu hayırlı, faziletli ve kıraat âlimi ${ }^{50}$ diye överken, Dârekutnî (ö. 385/995) ise âbid ve faziletli bir kimse olarak övmüştür. Yukarıda verilen bilgilerden kıraat ilminde mütehassıs ve âlim olduğu anlaşılan İmam Halef, Cehmiyye'den korunmak için gizli olarak yaşadığı bir dönemde 229/844 yılında Bağdat'ta vefat etmiş ve Künase mezarlığına defnedilmiştir. ${ }^{51}$

\section{Halef b. Hişâm'ın Hadisçilik Yönü}

Kıraat ilminde ihtisaslaşan Halef b. Hişâm (ö. 229/844), hadis ilminde de ismi zikredilen âlimlerden biri olmuştur. Onun yaşadığı hicri 150 ile 229 yılları arası hadislerin sözlü ve yazılı olarak nakledildiği bir dönem olmakla birlikte, ilk tasnif edilen hadis kitaplarından bazıları onun çocukluk dönemlerine rast gelmektedir. Bunlara İbn Ebû Zi'b (ö. 159/776) ve İmam Mâlik'in (ö. 179/795) Muvattalar'ını, İbn Cüreyc (ö. 150/767), İbn İshak (ö. 151/768), Ma'mer b. Râşid (ö. 153/770), İbn Ebû Arûbe (ö. 156/773), Evzâî (ö. 157/774), Süfyân es-Sevrî (ö. 161/778) gibi âlimlerin kitapları örnek verilebilir. Bu eserler aynı zamanda kendilerinden sonra yazılacak hadis kitapları için bir asıl ve örneklik teşkil etmişlerdir. ${ }^{52}$ Böyle bir dönemde yaşaması sebebiyle onun hadis ilmi alanındaki durumunun bilinmesi önem arz etmektedir.

0 , zamanının muhaddislerinden hadis öğrenmiş ve ondan da birçok kimse hadis rivayet etmiştir. Yine ondan nakledilen hadisler meşhur hadis kitaplarından bazılarında geçmektedir. Onun kendilerinden rivayette bulunduğu hocaları arasında Abdü Rabbihî b. Nâfi' Ebû Şihâb el-Hannâd (ö. 172/789), Ebû Avâne Vaddâh b. Abdillâh el-Vâsitî (ö. 176/792), Şerîk b. Abdullâh b. Hâris en-Nehaî (ö. 177/794), Ebu'l-Ahves Sellâm b. Süleym el-Kûfî (ö. 179/795), Hammâd b. Zeyd (ö. 179/795), Mâlik b. Enes (ö. 179/795), Hüşeym b. Beşîr el-Vâsıtî (ö. 183/799), Abdülazîz b. Muhammed b. Ubeyd ed-Derâverdî (ö. 187/803), Süleym b. İsa (188/804), Abdullah b. Yahya et-Tev'em ve Hammâd b. Yahya el-Ebah gibi âlimler zikredilebilir. ${ }^{53}$

İmam Halef'in kendilerinden rivayette bulunduğu hocalarına bakıldı̆̆ında onların Peygamberimiz'in övdüğü nesil olan etbâu't-tâbiînden olduğu görülmektedir. ${ }^{54}$ Yine bunlardan Mâlik b. Enes, Abdü Rabbihî b. Nâfi', Hammâd b. Zeyd, Ebû Avâne Vaddâh b. Abdillâh el-Vâsttî, Abdülazîz b. Muhammed b. Ubeyd edDerâverdî, Hüsseym b. Beşîr el-Vâsıtî gibi âlimler hadis rivayetinde hâfiz, hüccet ve

\footnotetext{
${ }^{49}$ Zehebî, Siyer,10/579; a.mlf., Ma'rifetü'l-Kurrâi'l-Kibâr, 1/421.

50 Ebû Hâtim Muhammed b. Hibbân b. Ahmed el-Büstî, es-Sikât, (Haydarabad: Dâiretü'l-Meârifi'lOsmaniyye, 1393/1973), 8/228.

51 Zehebî, Siyer, 10/580; İbnü'l-Cezerî, Gâyetü’n-Nihaye, 1/247; Altıkulaç, “Halef b. Hişâm”, 15/237.

52 Muhammed Mustafa A'zamî, İlk Devir Hadis Edebiyatı, çev. Hulusi Yavuz (İstanbul: İz Yayınları, 1993), 32.

${ }^{53}$ Bk. Mizzî, Tehzîbü'l-Kemâl, 8/300; Zehebî, Siyer, 10/577; İbn Hacer, Tehzîbü't-Tehzîb, 3/156.

54 Bk. Buhârî, Sahîhu'l-Buhârî, "Şehâdât", 9; "Fezâilü Ashâbi'n-Nebî", 1; Müslim, Sahîh-i Müslim "Fezâilü's-Sahâbe", 210, 211, 212.
} 
sika olarak değerlendirilen kişiler olmakla birlikte, etbâu't-tâbiîn döneminde hadislerin kendilerinden nakledildiği kavşak noktaları konumundadırlar. Bu âlimlerden nakledilen rivayetler başta kütüb-i sitte olmak üzere hadis kitaplarında bulunmaktadır.

Halef b. Hişâm kıraat dersi vermenin yanında hadis rivayetinde de bulunmuștur. Onun bu durumunu aynı zamanda talebesi de olan el-Hüseyin b. Fehm (ö. 289/902) Halef'in ilim öğretmeye öncelikle Kur'an okuyan öğrencilerinden bașladığını, sonra hadis talebelerine ders verdiğini ifade ettikten sonra "Bize Ebû Avâne'nin rivayet ettiği hadislerden 50 tane okurdu." diyerek nakletmiştir. ${ }^{55}$

Ondan birçok kişi hadis öğrenmiştir. ${ }^{56}$ Ondan hadis rivayet eden talebeleri arasında Ahmed b. Hanbel (ö. 241/855), Müslim b. el-Haccâc el-Kuşeyrî (ö. 261/875), Ebû Zür'a er-Râzî (ö. 264/878), Abbas b. Muhammed ed-Dûrî (ö. 271/884), Ebû Dâvûd Süleymân b. el-Eş'as (ö. 275/889), Ebû Hâtim er-Râzî (ö. 277/890), Ahmed b. Züheyr b. Harb (ö. 279/892), Ahmed b. Yahyâ b. Câbir elBelâzürî (ö. 279/892), İbrâhîm b. İshâk b. İbrâhîm el-Harbî (ö. 285/899), elHüseyin b. Fehm (ö. 289/902), Abdullah b. Ahmed b. Hanbel (ö. 290/903), İdrîs b. Abdülkerîm el-Haddâd (ö. 292/905), Musa b. Harun el-Hammâl (ö. 294/907), Muhammed b. Yahya b. Süleyman el-Mervezî (ö. 298/911), Muhammed b. İbrahim b. Ebân es-Serrâc (ö. 306/918), Ebû Ya'lâ Ahmed b. Alî b. el-Mevsllî (ö. 307/919), Ebü'l-Kâsım Abdullâh b. Muhammed el-Begavî (ö. 317/929) ve Muhammed b. Halef b. Hişâm gibi âlimler bulunmaktadır.

İmam Halef'in, ismi zikredilen talebelerinin çoğunluğu, cerh-ta'dîl âlimleri tarafından hâfız, sebt, sika gibi en üstün terimlerle değerlendirilen âlimler olmalarının yanında bir kısmı da eser sahibi kimseler olup; bunların eserleri günümüze kadar ulaşmıştır. Bunlar arasında Ahmed b. Hanbel, Müslim b. el-Haccâc elKuşeyrî, Ebû Dâvûd Süleymân b. el-Eş'as, Ebû Zür'a er-Râzî, Ebû Hâtim er-Râzî, Ahmed b. Yahyâ b. Câbir el-Belâzürî, İbrâhîm b. İshâk b. İbrâhîm el-Harbî, Ebû Ya'lâ Ahmed b. Alî b. el-Mevsılî, Ebü'l-Kâsım Abdullâh b. Muhammed el-Begavî zikredilebilir. Bu muhaddislerden bir kısmı cerh-ta'dîl âlimi olmalarının yanında hadis ilminde otorite kabul edilen kimselerdir. ${ }^{57}$ Yine Ahmed b. Züheyr b. Harb ve İdrîs b. Abdülkerîm el-Haddâd gibi talebeleri ondan hem kıraat hem de hadis dersi almıșlardır. Böyle önemli talebelere hocalık yapmış olması İmam Halef'in hadis ilminde de ihtisas sahibi olduğunun apaçık göstergelerinden biridir. Nitekim talebeleri tasnif ettikleri hadis kitaplarında ondan naklettikleri rivayetlere yer vermişlerdir. ${ }^{58}$ Şimdi talebelerinin eserlerinde ondan yaptıkları rivayetlerle ilgili bilgiler aktarıla-

${ }^{55}$ Zehebî, Siyer, 10/579; a.mlf., Ma'rifetü'l-Kurrâi'l-Kibâr, 1/421.

${ }^{56}$ Bk. Mizzî, Tehzîbü'l-Kemâl, 8/300-301; Zehebî, Siyer, 10/577; İbn Hacer, Tehzîbü't-Tehzîb, 3/156.

${ }^{57}$ Emin, Așıkkutlu, "Cerh ve Ta'dil” Türkiye Diyanet Vakfı İslâm Ansiklopedisi (İstanbul: TDV Yayınları, 1993), $7 / 396$.

58 Ebû Abdillâh Ahmed b. Muhammed b. Hanbel eș-Șeybânî el-Mervezî, el-Müsned (Beyrut: Müessesetü'r-Risale, 1420/1999), 33/356, (No. 20187); 33/358 (No. 20191); Müslim, Sahîh, "Nikâh",140 (No. 1442); Ebû Dâvûd Süleymân b. el-Eş'as b. İshâk es-Sicistânî el-Ezdî, es-Sünen (İstanbul: Çağrı Yayınları, 1992), "Savm”, 13 (No. 2339); Ebû Ya'lâ Ahmed b. Alî el-Mevsılî, Müsnedü'lİmam Ebî Ya'lâ (Kahire: Dâru't-Te'sîl, 1438/2017), 1/262 (No:103); 1/372, (No. 372 ve 373). 
caktır.

Kütüb-i sitte imamlarından sadece Müslim ve Ebû Dâvud ondan rivayette bulunmușlardır. Buhârî’nin (ö. 256/870) sekiz defadan fazla Bağdat'a gittiği halde Ahmed b. Hanbel gibi oranın muhaddislerinden rivayette bulunmasına rağmen ${ }^{59}$ ondan rivayette bulunmadığı görülmektedir. Bunun sebebi İmam Halef'in kıraat ilminde ön planda olmasıyla açıklanabileceği gibi, onunla karşılaşma imkânı olmaması da olabilir. Karşılaşmama sebeplerinden birisi de Halef b. Hişâm'ın ömrünün son zamanlarında Cehmiyye'den korunmak için gizli olarak yaşaması olabilir. ${ }^{60}$ Tirmizî (ö. 279/892), Halef b. Hişâm'ın vefatından sonra hicri 235 yılında ilim tahsiline çıktığı için ondan rivayette bulunamamıștır.61 İbn Mâce (ö. 273/887) Bağdat'a gelmiş ve Züheyr b. Harb (ö. 234/849) gibi Bağdatlı muhaddislerden ilim öğrenmiştir. ${ }^{2}$ Fakat onun İmam Halef'ten rivayeti bulunmamaktadır. İmam Halef vefat ettiğinde 20 yaşında olan İbn Mâce muhtemelen onun ölümünden sonra Bağdat'a gelmiş ve bu sebeple ondan rivayette bulunamamıștır. Nesâî (ö. 303/915) Halef b. Hişâm vefat ettiğinde 14 yaşında bulunmaktadır. Nesâî, İmam Halef'in vefatından ancak altı yıl sonra 20 yaşındayken ilim yolculuğuna başlamıştır. ${ }^{63} \mathrm{Bu}$ sebeple Nesâî de ondan rivayette bulunamamıştır.

Araştırmamız sonucunda Kütüb-i Sitte müelliflerinden Müslim ve Ebû Dâvud'un kitaplarında ondan aldıkları rivayetler ile ilgili șu bilgilere ulașılmıștır. Sahîh-i Müslim'de İmam Müslim'in, Halef b. Hişâm'dan 22 rivayeti bulunmaktadır. $\mathrm{Bu}$ rivayetlerin yirmisini İmam Halef hocası Hammâd b. Zeyd'den (ö. 179/795) rivayet ederken, bir rivayeti İmam Mâlik'ten ${ }^{64}$ (ö. 179/795) ve bir tanesini ise Ebu'l-Ahves'ten $^{65}$ (ö. 179/795) rivayet etmiştir. Bu 22 rivayetin geçtiği kitap ismi, hadis numarası ve o kitaptaki toplam hadis sayısı aşağıdaki tabloda verilmiştir.

Tablo 1. Halef b. Hişâm'ın Sahîh-i Müslim'de Geçen Rivayetlerinin Konulara Göre Dağıllımı

\begin{tabular}{|c|c|c|}
\hline Kitap İsmi & Bab Numarası & Toplam Hadis Sayısı \\
\hline Îmân & 23,136 & 2 \\
\hline Hayz & 62 & 1 \\
\hline Salât & $2,114,188,195$ & 4 \\
\hline $\begin{array}{c}\text { Kitâbü'l-Mesâcid ve Mevâzı's- } \\
\text { Salât }\end{array}$ & 29,238 & 2 \\
\hline Salâtü'l-Müsâfirîn ve Kasrihâ & 10,157 & 2 \\
\hline Cenâiz & 25 & 1 \\
\hline
\end{tabular}

59 Muhammed Mustafa el-A‘zamî, "Buhârî, Muhammed b. İsmâil” Türkiye Diyanet Vakfi İslâm Ansiklopedisi (İstanbul: TDV Yayınları, 1992), 6/368.

60 İbnü'l-Cezerî, Gâyetü'n-Nihaye, 1/247; Altıkulaç, “Halef b. Hişâm” 15/237.

61 M. Yaşar Kandemir, "Tirmizî” Türkiye Diyanet Vakfı İslâm Ansiklopedisi (İstanbul: TDV Yayınları, 2012), 41/202.

62 Zehebî, Siyer, 13/278.

63 İbn Hacer, Tehzîbü't-Tehzîb, 1/38.

${ }^{64}$ Müslim, Sahîh, "Nikâh",140 (No. 1442).

${ }^{65}$ Müslim, Sahîh, “Kitâbü'l-Mesâcid ve Mevâzıı's-Salât”, 29 (No. 535). 


\begin{tabular}{|c|c|c|}
\hline Kitap İsmi & Bab Numarası & Toplam Hadis Sayısı \\
\hline Hac & 146,250 & 2 \\
\hline Nikâh & 76,140 & 2 \\
\hline Eymân & 7 & 1 \\
\hline İmâre & 95,161 & 2 \\
\hline Eşribe & 39 & 1 \\
\hline Fezâilü's-Sahâbe & 79 & 1 \\
\hline Kitâbü'z-Zikr ve'd-Dua ve't- & 45 & 1 \\
\hline Toplam & & $\mathbf{2 2}$ \\
\hline
\end{tabular}

Ebû Dâvûd, es-Sünen'inde Halef b. Hişâm'dan iki rivayette bulunmuş olup, ilk rivayette Halef'in hadis aldığı hocası Ebû Avâne el-Vâsıtî (ö. 176/792) iken66, ikinci rivayette ise hocası Ebû Şihâb el-Hannâd (ö. 172/789)'dır.67 Ebû Dâvûd, Halef'ten

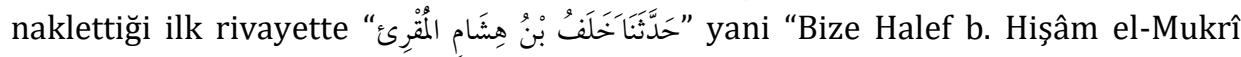
tahdîs etti." diyerek hocasının "kâri" olduğuna özellikle vurgu yapmıștır. Halef b. Hişâm'ın hocası Ebû Avâne el-Vâsıtî’den naklettiği rivayet Melâhim kitabında iken, Ebû Şihâb el-Hannâd'dan naklettiği rivayet ise Savm kitabındadır.

Ayrıca Ebû Dâvûd, es-Sünen'inde “Kitâbü'l-Hurûf ve'l-Kırâât” adıyla bir kitap açmış ve bu kitapta kıraatle ilgili bazı rivayetleri toplamıştır. Bu kitapta Ebû Saîd el-Hudrî’nin rivayet ettiği “Rasûlullâh (s.a.s) içerisinde جنبريل ile ميكال kelimelerinin geçtiği bir söz söyledi." hadisinden sonra Ebû Dâvûd, Halef'in şu sözünü nakletmiştir. "Ben kırk senedir kıraatlerle ilgili șeyler yazmaktan kalemimi kaldırmış değilim. ميكائل velimeleri kadar hiçbir kelime beni yormadı."68 Burada Ebû

Dâvûd'un kıraatle ilgili bir hadisin açıklamasında hocası Halef'in görüşünü kullandığı görülmektedir. Bu iki kelimenin yazılışının zorluğu yanında kıraat imamlarına göre birçok farklı okunuş şekilleri bulunmaktadır. ${ }^{69}$

Ahmed b. Hanbel'in el-Müsned'inde de Halef b. Hişâm'ın rivayetleri bulunmaktadır. Bu rivayetlerin bir kısmı Ahmed b. Hanbel'in İmam Halef'ten kendi rivayetleri iken bazıları da oğlu Abdullah'ın Halef'ten naklettiği rivayetlerdir. Bu rivayetlerin toplamı 17'dir.

el-Müsned'de, Ahmed b. Hanbel'in Halef b. Hişâm'dan dört rivayeti bulunmaktadır. Bu rivayetlerden iki tanesinde Halef'in hocası Ebû Avâne el-Vâsıtî̀ ${ }^{70}$ (ö. 176/792) iken, iki tanesinde ise Hammâd b. Zeyd ${ }^{71}$ (ö. 179/795)'dir.

el-Müsned'de, Abdullah b. Ahmed b. Hanbel'in Halef b. Hişâm'dan 13 rivayeti

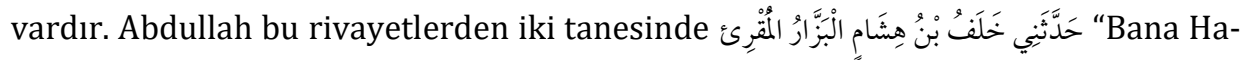

\footnotetext{
${ }^{66}$ Ebû Dâvûd, es-Sünen, "Savm”, 13 (No. 2339).

67 Ebû Dâvûd, es-Sünen, Melâhim, 17 (no. 4337).

${ }^{68}$ Ebû Dâvûd, es-Sünen, "Kitâbü'l-Hurûf ve'l-Kırâât”, 1 (No. 3998)

${ }^{69}$ bk. Ebû Amr Osmân b. Saîd b. Osmân ed-Dânî, et-Teysîr fi'l-Kırââti's-Seb'a (Beyrut: Dâru'l-Kitâbi'lArabî, 1404/1984), 75; Öztoprak, Kur'an Kıraatı, 322.

${ }^{70}$ Ahmed b. Hanbel, el-Müsned, 33/356, (No. 20187); 33/358 (No. 20191).

${ }^{71}$ Ahmed b. Hanbel, el-Müsned, 28/513 (No. 17277); 35/125 (21197).
} 
lef b. Hişâm el-Mukrî rivayet etti." diyerek hocasının "kâri" olduğunu belirtmiştir."2 İmam Halef'in gerek Ebû Dâvûd gerekse Abdullah b. Ahmed b. Hanbel gibi muhaddisler tarafından "mukrî” olarak tanıtılması, yaşadığı zamanda ilim ehli yanında kıraat ilminde meşhur olduğunun göstergesidir.

Abdullah'ın, Halef b. Hişâm'dan naklettiği rivayetlerin beş tanesinde Hişâm'ın hocası Ebu'l-Ahves ${ }^{73}$ (ö. 179/795), üç tanesinde Ebû Avâne el-Vâsıtî74 (ö. 176/792), iki tanesinde Hammâd b. Zeyd ${ }^{75}$ (ö. 179/795) ve Şerîk b. Abdullâh en$\operatorname{Nehaî}^{76}$ (ö. 177/794) iken, bir rivayette ise Âmir b. Ebî Âmir'dir. ${ }^{77}$

Ahmed b. Hanbel'in el-Müsned'indeki 17 rivayetin konusu, hadis numarası ve o konudaki toplam hadis sayısı aşağıdaki tabloda verilmiştir.

Tablo 2. Halef b. Hişâm'ın Ahmed b. Hanbel'in el-Müsned'inde Geçen Rivayetlerinin Konulara Göre Dağılımı

\begin{tabular}{|c|c|c|}
\hline Kitap İsmi & Hadis Numarası & Toplam Hadis Sayıs \\
\hline Tahâret & 1046,1047 & 2 \\
\hline Salât & $20191,20913,21207,21273$ & 4 \\
\hline Salâtü'l-Îdeyn & 20919 & 1 \\
\hline Savm & 21197 & 1 \\
\hline Hac & 20916 & 2 \\
\hline Hudût & 20914,20915 & 1 \\
\hline Diyet & 17277 & 1 \\
\hline Taâm & 20918 & 1 \\
\hline Eşribe & 20187 & 1 \\
\hline İmâre & 20905 & 1 \\
\hline Rüya & 1070 & $\mathbf{1 7}$ \\
\hline Birr ve Sıla & 15403 & 1 \\
\hline Toplam & & 1 \\
\hline
\end{tabular}

Halef b. Hişâm'ın rivayetleri talebesi olan Ebû Ya'lâ'nın el-Müsned'inde de bulunmaktadır. Onun el-Müsned'de Halef'ten aldığı 41 rivayeti bulunmaktadır. Halef b. Hişâm bu rivayetlerin 16 tanesini hocası Ebu'l-Ahves'ten ${ }^{78}$ (ö. 179/795), 15 tanesini Ebû Avâne el-Vâsıtî'den ${ }^{79}$ (ö. 176/792), 9 tanesini Hammâd b. Zeyd'den ${ }^{80}$

\footnotetext{
72 Ahmed b. Hanbel, el-Müsned, 34/461 (No. 20905); 34/465 (No. 20913).

73 Ahmed b. Hanbel, el-Müsned, 2/309 (No. 1046); 2/310 (No. 1047); 34/465 (No. 20913); $34 / 466$ (20916); 35/195 (No. 21273).

${ }^{74}$ Ahmed b. Hanbel, el-Müsned, 2/321 (1070); 34/467 (20918); 34/467 (20919).

${ }^{75}$ Ahmed b. Hanbel, el-Müsned, 34/461 (No. 20905); 35/134 (No. 21207).

${ }^{76}$ Ahmed b. Hanbel, el-Müsned, 34/465 (No. 20914 ve 20915).

77 Ahmed b. Hanbel, el-Müsned, 24/129 (No. 15403)

78 Ebû Ya'lâ Ahmed b. Alî el-Mevsılî, el-Müsned, Bazıları için bk. 1/262 (No:103); 1/372, (No. 372 ve 373); $1 / 424$ (No. 496 ve 497); 2/59 (No. 946); 2/310 (No. 1642).

${ }^{79}$ Ebû Ya'lâ el-Mevsılî, el-Müsned, Bazıları için bk. 2/242 (No. 1511); 2/253 (No. 1535 ve 1536); $3 / 12$ (No. 2355); 3/14 (No 2360 ve 2361).
} 
(ö. 179/795) ve bir tanesini ise Ali b. Müshir'den ${ }^{81}$ (ö. 189/805) rivayet etmiştir. $\mathrm{Bu} 41$ rivayetin konusu, hadis numarası ve o konudaki toplam hadis sayısı aşağıdaki tabloda verilmiştir.

Tablo 3. Halef b. Hişâm'ın Ebû Ya'lâ el-Mevsılî̀nin el-Müsned'inde Geçen Rivayetlerinin Konulara Göre Dağılımı

\begin{tabular}{|l|l|l|}
\hline Konu & Hadis Numarası & Hadis Sayısı \\
\hline Tahâret & $496,497,1642,2361$ & 4 \\
\hline Salât & $\begin{array}{l}2355,2366,2861,2863,2866,3912,4779, \\
5766,7542\end{array}$ & 9 \\
\hline Savm & 1411,2364 & 2 \\
\hline Hac & $2360,5734,7071$ & 3 \\
\hline Edâhî & 1535 & 1 \\
\hline Eymân & 7271 & 1 \\
\hline Büyû' & 2365,5735 & 2 \\
\hline Müzâraat & 2862 & 1 \\
\hline Fezâilü'l-Kur'an & $1522,2363,7257$ & 3 \\
\hline Tefsîri'l-Kur'an & 103 & 1 \\
\hline İlim & 4102 & 1 \\
\hline Cihâd ve's-Siyer & 1536 & 1 \\
\hline Bir ve Sıla & 1963 & 1 \\
\hline Dua & 2362,6806 & 2 \\
\hline Tevbe & 5767 & 1 \\
\hline Fiten & 946 & $\mathbf{4 1}$ \\
\hline Kader & 372,373 & 1 \\
\hline Vasiyyet & 1511 & 1 \\
\hline Zikir & $4101,6182,7272$ & 1 \\
\hline Zühd & 2860 & 1 \\
\hline Toplam: & & 1 \\
\hline & & 1 \\
\hline
\end{tabular}

Dört eser içinde Halef b. Hişâm'dan rivayet edilen en çok hadis, 41 rivayetle Ebû Ya'lâ'nın el-Müsned'inde, sonra sırasıyla 22 rivayetle Sahîh-i Müslim'de, 17 rivayetle Ahmed b. Hanbel'in el-Müsned'inde ve 2 rivayetle Ebû Dâvûd'un esSünen'inde bulunmaktadır. İsmi zikredilen dört eserde Halef b. Hişâm'dan nakledi-

\footnotetext{
$\longrightarrow$

${ }^{80}$ Ebû Ya'lâ el-Mevsılî, el-Müsned, Bazıları için bk. 2/200 (No. 1411), 2/249 (1522); 3/531 (No. 4101 ve 4102).

${ }^{81}$ Ebû Ya'lâ el-Mevsılî, el-Müsned, 5/289-290 (No. 7071).
} 
len toplam 82 rivayet bulunmaktadır. Halef b. Hişâm bu rivayetlerin 33'ünü hocası Hammâd b. Zeyd'den, 22'sini Ebu'l-Ahves'ten, 21'ini Ebû Avâne el-Vâsıtî'den, 2'sini Şerîk b. Abdullâh'tan rivayet ederken, Ali b. Müshir, İmam Mâlik, Âmir b. Ebî Âmir ve Ebû Şihâb el-Hannâd'dan ise birer hadis rivayet etmiştir.

Halef b. Hişâm'dan rivayet edilen toplam 82 rivayetin yaklaşık on tanesi metin olarak benzer rivayetler iken, diğer 72 rivayet ise metin olarak birbirlerinden farklıdır. Ondan nakledilen rivayetlerin çoğunluğunun içerik olarak öncelikle namaz, sonra ise temizlikle ilgili olduğu görülmektedir. Yine ondan nakledilen rivayetler içinde kıraatle ilgili hadisler bulunmazken, Kur'an'ın faziletiyle ilgili dört ve Kur'an'ın tefsiriyle ilgili de bir rivayet olduğu görülmektedir.

İmam Halef' in hadisle ilgili bir eserinin olduğuna dair kaynaklarda bir bilgiye rastlanmamıştır. Döneminin büyük muhaddislerinden hadis öğrenen ve kendisinden sonraki önemli muhaddislere hocalık yapan Halef b. Hişâm’ın hadisçiliğiyle ilgili cerh-ta'dîl âlimleri onu öven sözler sarf etmişlerdir. Yahya b. Maîn (ö. 233/848), Ahmed b. Hanbel (ö. 241/855) ve Nesâî (ö. 303/915) ona "sika" derken $^{82}$ Zehebî (ö. 748/1348) onun "hâfız" ve "hüccet" olduğunu ${ }^{83}$ söylemiştir. İbn Hibbân (ö. 354/965) "onun kıraat âlimi ve sağlam hadis hâfızlarından biri olduğunu" ifade ederken84, İbn Hacer (ö. 852/1449) ise "hadis rivayetinde önde gelen, sünnete bağlı ve sika olduğuna" işaret etmiștir. 85 Zehebî onu 12. tabaka muhaddisleri içinde zikrederken ${ }^{86}$, İbn Hacer ise 10 . tabakada zikretmiştir. ${ }^{87}$ Verilen bilgilerden de anlaşılacağı üzere Halef b. Hişâm kıraat imamı olmasının yanında hadis ilminde de önemli bir muhaddis olduğu görülmektedir.

\section{Sonuç}

İslâmî ilimler birbiriyle irtibatlı ilim dalları olup, onlarla ilgilenen kişilerin bunların herbirinden ihtiyaç oranında bilgi sahibi olmaları gerekmektedir. İslâmî ilimlerle iştiğal edenler zamana, ilgisine ve kapasitesine göre bunlardan birinde bazen de birkaçında ihtisas sahibi olmuşlardır. Bu şekilde birkaç ilim dalında derinleşen âlimlerden biri de 150-229/767-844 yılları arasında yaşamış ve hadis ve kıraat alanında temayüz etmiş olan Halef b. Hişâm'dır. Hadis ve kıraat rivayetle gelen ilimler olması ve kıraatle ilgili rivayetlerin hadis kitaplarında bulunması sebebiyle birbirleriyle ilgili ilimlerdir. Bu sebeple İmam Halef'in kıraatte mahir bir âlim olmasında hadis ilmindeki ihtisasının da etkili olduğu anlaşılmaktadır.

Halef b. Hişâm öncelikle kıraat alanında kendisini geliştirmiştir. Zamanındaki önemli kârilerden kıraat öğrenen İmam Halef'in kıraatte isnadı yedi kıraat imamlarından olan Nâfi' b. Abdurrahman, Âsım b. Behdele ve Hamza b. Habîb'e ulaşmakta ve onların senedleriyle de Peygamberimize ulaşmaktadır. Kaynaklarda

\footnotetext{
82 Zehebî, Ma'rifetü'l-Kurrâi'l-Kibâr, 1/421; İbn Hacer, Tehzîbü't-Tehzîb, 3/156-157.

83 Zehebî, Siyer, 10/576.

84 İbn Hibban, es-Sikât, 8/228

85 İbn Hacer, Tehzîbü't-Tehzîb, 3/157.

${ }^{86}$ Zehebî, Siyer, 10/576-580.

${ }^{87}$ Ebü'l-Fazl Şihâbüddîn Ahmed b. Alî b. Muhammed el-Askalânî, Takrîbü't-Tehzîb (Suriye: Dâru'r-Reşîd, 1406/1968), 1/194.
} 
kıraat ilmiyle ilgili eserleri olduğu söylenen Halef'in bu eserlerinin günümüze ulaştığıyla ilgili bir bilgiye ulaşılamamıştır. Yedi kıraat imamından biri olan Hamza b. Habîb'in iki râvisinden biri olarak tercih edilen Halef b. Hişâm, kıraat ilmindeki isabetli tercihleri sebebiyle kıraati aşere sisteminde onuncu imam olarak kabul edilmiştir. Kıraat ilmi konusunda önemli talebeler de yetiştiren İmam Halef'in k1raati, kırâati aşere sistemi içinde öğretilmeye devam edilmektedir.

Halef b. Hişâm kıraat ilmi yanında hadis ilminde de derinleşmiştir. Çoğunluğu hadis ilminde otorite kabul edilen muhaddislerden hadis öğrendi. Ondan da hadis ilminde ön plana çıkmıș talebeleri hadis öğrenmiştir. Onun rivayet ettiği hadisler aynı zamanda musannif olan talebelerinin eserleri ve diğer muhaddislerin eserleri vasıtasıyla günümüze ulaşmıştır. 0 , bildikleriyle amel eden sünnete bağlı bir muhaddis olmakla birlikte, hadis rivayet metodolojisinde hâfız, hüccet ve sika gibi tadîl lafızlarıyla nitelenmiștir. Netice olarak Halef b. Hişâm'ın hem kıraat hem de hadis alanında uzmanlaşmış iki yönlü bir âlim olduğu ortaya çıkmaktadır. Geçmişte yaşamış böyle âlimlerin tanıtılmasının gümümüz ilim ehlini teşvik etmesinin yanında onların ufkunu açacağı düşünülmektedir.

Funding / Finansman: This research received no external funding. / Bu araştırma herhangi bir dış fon almamıştır.

Conflicts of Interest / Çıkar Çatışması: The author declare no conflict of interest. / Yazar, herhangi bir çıkar çatışması olmadığını beyan eder.

\section{Kaynakça}

Ahmed b. Hanbel, Ebû Abdillâh Ahmed b. Muhammed b. Hanbel eş-Şeybânî el-Mervezî. elMüsned. thk. Şuayb el-Arnavûd. 50 Cilt. Beyrut: Müessesetü'r-Risale, 2. Basım, 1420/1999.

Akkuş, Murat, Yılmaz, Haşem . "Ebû Bekir Şu'be Rivayetinin Kur'ân'ın Anlaşılmasındaki Rolü". Sirat 1 / 2 (Kasım 2020): 142-169.

Akkuş, Murat, Aydın, Ramazan. "Türkiye'deki Farklı Kıraat Anlayışlarıyla İlgili Değerlendirmeler". Mütefekkir 3 / 6 (Aralık 2016): 289-306. https://doi.org/10.30523/mutefekkir.284537.

Altıkulaç, Tayyar. "Halef b. Hişâm" Türkiye Diyanet Vakfı İslâm Ansiklopedisi. 15/237-238. İstanbul: TDV Yayınları, 1997.

Altıkulaç, Tayyar. "İbn Muhaysın” Türkiye Diyanet Vakfı İslâm Ansiklopedisi. 20/209-210. İstanbul: TDV Yayınları, 1999.

Altıkulaç, Tayyar. “İbnü’l-Cezerî” Türkiye Diyanet Vakfı İslâm Ansiklopedisi. 20/551-557. İstanbul: TDV Yayınları, 1999.

Așıkkutlu, Emin. "Cerh ve Ta'dil” Türkiye Diyanet Vakfı Íslâm Ansiklopedisi. 7/394-401. İstanbul: TDV Yayınları, 1993.

A'zamî, Muhammed Mustafa. İlk Devir Hadis Edebiyatı. çev. Hulusi Yavuz. İstanbul: İz Yayınları, 1993.

A'zamî, Muhammed Mustafa. "Buhârî” Türkiye Diyanet Vakfi İslâm Ansiklopedisi. 6/368-372. İstanbul: TDV Yayınları, 1992.

A'zamî, Muhammed Mustafa. Vahyedilişinden Derlenişine Kur'an Tarihi. çev. Ömer Türker ve Fatih Serenli. İstanbul: İz Yayıncllık, 2006.

Birıșık, Abdulhamit. "Kıraat". Türkiye Diyanet Vakfi Íslâm Ansiklopedisi. 25/426-433. İstanbul: TDV Yayınları, 2002. 
Buhârî, Ebû Abdillâh Muhammed b. İsmail. Sahîhu'l-Buhârî. 3 Mücelled 8 Cilt. İstanbul: Çağrı Yayınları, 2. Basım, 1992.

İsmail Cerrahoğlu, Tefsir Usulü. Ankara, TDVY, 1985.

Çetin, Abdurrahman. Kur'ân-ı Kerîm'in İndirildiği Yedi Harf ve Kıraatlar. İstanbul: Ensar Yayınları, 3. Basım, 2013.

Dağ, Mehmet. Geleneksel Kıraat Algısına Eleştirel Bir Yaklaşım. Ankara: Türkiye Diyanet Vakfı Yayınları, 2. Basım, 2019.

Damra, Tevfîk İbrahim. Ferhatü'l-Ebrar fỉ Kırâat-i Halefi'l-Bezzâr. Amman: Dâru's-Sahâbe, $1429 / 2008$.

Dânî, Ebû Amr Osmân b. Saîd b. Osmân ed-Dânî. et-Teysîr fi'l-Kırââti's-Seb'a. Beyrut: Dâru'lKitâbi'l-Arabî, 2. Basım, 1404/1984.

Dânî, Ebû Amr Osmân b. Saîd b. Osmân ed-Dânî. el-Ahrufü's- Seb'a li'l-Kur'an. thk, Abdülmüheymin Tahhân. Mekke: Mektebetü'l-Menâra, 1408/1988.

Ebû Dâvûd Süleymân b. el-Eș'as b. İshâk es-Sicistânî el-Ezdî. es-Sünen. 5 Cilt. İstanbul: Çağrı Yayınları, 2. Basım, 1992.

Ebû Ya'lâ el-Mevsllî, Ahmed b. Alî el-Mevsllî. Müsnedü'l-İmam Ebî Ya'lâ (el-Müsnedü's-Sağîr). thk. Müşrif. Abdurrahman b. Abdullah b. Akîl. 5 Cilt. Kahire: Dâru't-Te'sîl, 1438/2017.

Eroğlu, Ali. “İbn Mihrân en-Nîsâbûrî" Türkiye Diyanet Vakfi İslâm Ansiklopedisi. 20/199-200. İstanbul: TDV Yayınları, 1999.

İbn Ebû Hâtim, Ebû Muhammed Abdurrahmân b. Muhammed b. İdrîs er-Râzî. el-Cerh ve'tTa'dîl, 9 cilt. Beyrut: Dâru İhyâi't-Türâsi'l-Arabî, 1371/1952.

İbnü'l-Cezerî, Ebü'l-Hayr Şemsüddin Muhammed b. Muhammed el-Cezerî. Müncidü'lMukrîîn ve Murşidü't-Tâlibîn. Beyrut: Dâru'l-Kütübi'l-İlmiyye, 1420/1999.

İbnü'l-Cezerî, Ebü'l-Hayr Șemsüddin Muhammed b. Muhammed el-Cezerî. Gâyetü'n-Nihaye fí Tabakâti'l-Kurrâi. 2 cilt. Beyrut: Dâru'l-Kütübi'l-İlmiyye, 1427/2006.

İbnü'l-Cezerî, Ebü'l-Hayr Şemsüddin Muhammed b. Muhammed el-Cezerî. en-Neşr fi'lKırââti'l-Aşr. nșr. Ali Muhammed ed-Dabbâ'. 2 cilt. Beyrut: Dârü'l-Kütübi'l-İlmiyye, ts.

İbn Hacer, Ebü'l-Fazl Şihâbüddîn Ahmed b. Alî b. Muhammed el-Askalânî. Tehzîbü't-Tehzîb. 12 Cilt. Haydarâbâd: Dâiratü'l-Meârifi'n-Nizâmiyye, 1325.

İbn Hacer, Ebü'l-Fazl Şihâbüddîn Ahmed b. Alî b. Muhammed el-Askalânî. Takrîbü't-Tehzîb. thk. Muhammed Avvâme. Suriye: Dâru'r-Reşîd, 1406/1968.

İbn Hibbân, Ebû Hâtim Muhammed b. Hibbân b. Ahmed el-Büstî. es-Sikât. 9 cilt. Haydarabad: Dâiretü'l-Meârifi'l-Osmaniyye, 1393/1973.

İbn Mücâhid, Ebû Bekir Ahmed b. Mûsâ b. el-Abbâs b. Mücâhid et-Temîmî. Kitâbü's-Seb`a fi'lKırâât. thk. Șevkī Dayf. Kahire: Dâru'l-Meârif, 1972.

İbn Şebbe, Ebû Zeyd Ömer b. Şebbe en-Nümeyrî el-Basrî. Târîhu'l-Medîneti'l-Münevvere. thk. Fehîm Muhammed Șeltût, 4 Cilt. Cidde: Habib Mahmud Ahmed Kütüphanesi, 1399/1979.

Kandemir, M. Yașar. “Tirmizî” Türkiye Diyanet Vakfı İslâm Ansiklopedisi. 41/202-204. İstanbul: TDV Yayınları, 2012.

Keskioğlu, Osman. Kur'an-ı Kerim Bilgileri. Ankara: TDVY. 1989.

Koyuncu, Recep. Kıraat İlmi ve Takrîb Usulü. Konya: Hacıveyiszade İlim ve Kültür Vakfi, 2018.

Maşalı, Mehmet Emin. Tarihi ve Temel Meseleleriyle Kıraat İlmi. Ankara: Otto Yayınları, 2. Basım, 2020.

Mizzî, Ebü’l-Haccâc Cemâlüddîn Yusuf b. Abdirrahmân. Tehzîbü'l-Kemâl fí Esmâi'r-Ricâl. thk. Beșşâr Avvâd Ma'rûf. 35 Cilt. Beyrut: Müessesetü'r-Risâle, 1400/1980.

Müslim, Ebü'l-Hüseyn Müslim b. el-Haccâc el-Kușeyrî. Sahîh-i Müslim. 3 Cilt. İstanbul: Çağrı Yayınları, 2. Basım, 1992.

Öztoprak, Sirâceddin. Kur'an Kıraatı -Kıraâtı Așere. İstanbul: Beyan Yayınları, 2. Basım, 2012.

Süyûtî, Ebü'l-Fazl Celâlüddîn Abdurrahmân b. Ebî Bekr b. Muhammed. el-İtkân fi Ulûmi'l 
Kur'ân. thk. Şuayb el-Arnavûd. Beyrut, Müessesetü'r-Risâle, 1429/2008.

Şengül, İdris. "Seleme b. Âsım" Türkiye Diyanet Vakfı İslâm Ansiklopedisi. 36/405-406. İstanbul: TDV Yayınları, 2012.

Yerlikaya, Cafer. Halef el-Bezzâr ve Kırâati. Sivas: Cumhuriyet Üniversitesi, Sosyal Bilimler Enstitüsü, Yüksek Lisans, 2014.

Yerlikaya, Cafer. "Halef Kırâati Özelinde Kırâatlerle İlgili Bazı Tahlil ve Tespitler", KSÜ İlahiyat Fakültesi Dergisi 36 (Aralı 2020), 307-344. https://doi.org/10.35209/ksuifd.766606

Zehebî, Ebû Abdillâh Şemsüddîn Muhammed b. Ahmed b. Osmân, Siyeru A'lâmi'n-Nübelâ. thk. Şuayb el-Arnavut. 23 Cilt. Beyrut: Müessesetü'r-Risale, 7. Basım, 1410/1990.

Zehebî, Ebû Abdillâh Şemsüddîn Muhammed b. Ahmed b. Osmân, Ma'rifetüll-Kurrâi'l-Kibâr Alet-Tabakâti ve'l-Âsâr. thk. Tayyar Altıkulaç. 4 Cilt. İstanbul: Türkiye Diyanet Vakfı İslam Araştırmalar Merkezi Yayınları, 1995. 